\title{
A cross-cultural examination of the relationships among human resource management practices and organisational commitment: an institutional collectivism perspective
}

Joseph C. Rode, Xiaowen Huang, Barbara Flynn

\begin{abstract}
Previous research has shown that human resource management (HRM) practices vary across cultures. However, research has seldom empirically compared the effects of various HRM practices on firm-level or individual-level outcome variables across cultures. Drawing upon psychological contract theory and the literature on cultural values, the present study examined the effects of three organizational-level HRM practices on individual organizational commitment in a survey of 2,424 individuals in 120 organizations located in four countries and three industries. Based upon the GLOBE study, we classified the four countries into two groups - high versus low institutional collectivism. The results of our hierarchical linear modeling (HLM) analyses found significant differences in the effects of organizational-level HRM on individual organizational commitment across cultures for two of the three HRM practices included in our model: training and teamwork. We also found partial support for differences across cultures for the effects of the third HRM practice: employee involvement in decision making. Overall, our results support the utility of theoretical and empirical models that address multiple levels of analyses to better understand the mechanisms through which the HRM-performance link takes place across national cultures.
\end{abstract}

Keywords: Cultural values, institutional collectivism, human resource management, organizational commitment

This is the author's manuscript of the article published in final edited form as:

Rode, J. C., Huang, X., \& Flynn, B. (2016). A cross-cultural examination of the relationships among human resource management practices and organisational commitment: an institutional collectivism perspective. Human Resource Management Journal, 26(4), 471-489.

http://dx.doi.org/10.1111/1748-8583.12117 
A significant body of research has examined differences in human resource management (HRM) practices across nations (Aycan 2005; Aycan et al., 2000; Bowen, Galang, \& Pillai, 2002; Brewster \& Mayrhofer, 2012; Peretz \& Rosenblatt, 2011). Although the literature has made considerable progress in identifying the relationships between various national cultural values and HRM configurations, research to date has largely focused on comparing HRM practices across cultures rather than comparing the relationships between various HRM practices and either firm-level or individual-level outcome variables (Reiche, Lee, \& Quintanilla, 2012). With the exception of Andreassi and Lawter's (2014) job satisfaction study, the few studies that have examined the relative effects of HRM practices across cultures have relied on small samples of relatively few organizations within only two countries, limiting the generalizability of findings (Amanthram \& Chan, 2013; Caliguiri, 2014; Lincoln \& Kalleberg, 1985). Thus, while a fair amount is known about how HRM practices vary across cultures, little is known about the relative effects of HRM practices across cultures.

Moreover, even in single country samples, most strategic HRM research has adopted the firm as the unit of analysis and relied on aggregate measures to evaluate the impact of HRM practices on employee outcomes. This macro-level approach captures outcomes at the collective level but neglects variations among individual employees, thereby making the implicit assumption that all employees exhibit the same level of the outcome variable in question. Several recent studies have challenged this assumption by reporting that employee reactions to HRM practices differ both from their managers (Liao, Toya, Lepak, \& Hong, 2009) and from other employees exposed to the same HRM practices (Nishii, Lepak, \& Schneider, 2008). These results highlight the fact that HRM practices reside at the organizational level but individual outcomes, such as organizational commitment or job performance, reside within the individual who is subject to those HRM practices. Aggregating individual-level phenomena to the organizational level significantly increases the possibility of spurious results, indicating 
the need for multi-level modeling (Raudenbush \& Bryk, 2002). Indeed, multi-level empirical models are particularly important in cross-cultural HRM research given that one's interpretation of and subsequent reactions to HRM practices can be significantly influenced by the extant culture (Budhwar \& Sparrow, 2002; Hofstede, 1983; Weller \& Gerhart, 2012). However, large-scale empirical investigations of the relationships among organizational-level HRM practices and individual outcomes are limited due to data and methodology constraints; rigorous, multi-level empirical studies of the effects of HRM practices are even fewer.

We address these gaps in the existing literature by examining the relationships between organizational-level HRM practices and individual-level organizational commitment across national cultures using a multi-level dataset that contains a multi-source sample of 2,424 employees from 120 organizations located in four countries and three industries. Our theoretical approach draws from psychological contract theory as well as the HRM and cross-cultural values literatures.

National culture consists of shared mental programs that exist within the population of a sovereign nation (Thomas \& Peterson, 2014). It shapes individual's basic assumptions (Hofstede, 1983) and strongly influences individual cognition (Abramson, Keating, \& Lane, 1996). As political entities, nations vary in their institutional norms and employment relations systems, thus making national culture particularly relevant in assessing the impact of HRM practices. We focus on the institutional collectivism dimension of national culture (House, Hanges, Javidan, Dorfman, \& Gupta, 2004), or the degree to which organizational practices are expected to value group interests over individual interests (Gilford, Bhawark, Nishii, \& Bechtold, 2004). Given its explicit focus on the workplace and the extent to which the self is viewed as an independent versus interdependent entity, we argue that institutional collectivism should play a significant role in how individuals scan, select, and interpret information from the work environment (Budhwar \& Sparrow, 2002), which has important implications for the formation of psychological contracts, or employees' expectations regarding the reciprocal obligations between themselves and their employers (Rousseau, 1989; Thomas, Au, \& Ravlin, 2003). 
Psychological contracts vary in the extent to which they are viewed as transactional vs. relational. Transactional psychological contracts emphasize exchanges of economic resources with a short-term orientation, while relational contracts highlight exchanges of socio-emotional resources with a long-term orientation. We posit that institutional collectivism cultural values influence individual employees' interpretation of HRM practices and affect the formation of psychological contracts. The resulting differences in the relative emphasis on transactional vs. relational psychological contracts, in turn, impact the effectiveness of HRM practices in cultivating individual organizational commitment, or the strength of the individual employee's bond to the organization (Mathieu \& Zajac, 1990). Organizational commitment is the initial focus of this research as it's an important factor mediating the relationship between HRM and several important outcomes, including turnover, organizational citizenship behavior, and organizational performance (Jiang, Takeuchi, \& Lepak, 2013; Sturges, Conway, Guest, \& Liefooghe, 2005).

Overall, our study makes two important contributions to the existing literature. First, from a theoretical perspective, we combine the cross-cultural HRM and the psychological contract literatures to theoretically ground explanations for how the effects of HRM practices at individual-level outcomes may vary across cultures. Second, from a methodological perspective, our analysis employs multi-level modeling to more accurately reflect the relationship between organization-level HRM practices and individual outcomes than previous research that has relied on aggregate measures of individual outcomes. These contributions allow us to show how the effects of specific organization-level HRM practices on individual-level employee outcomes differ across cultures. This cultural difference has important implications for practice and calls into question the universal applicability of HRM practices. While the "high commitment" HRM system that has received considerable research attention in recent years (Arthur, 1994; Gerhart, 2012; Jiang et al., 2013) may have some universal traits, our results indicate that the extent to which specific HRM practices affect individual outcomes may be culture-dependent. Specifically, we examine how the effects of employee training, employee involvement in decision 
making, and teamwork on individual organizational commitment differ in high versus low institutional collectivism cultures.

\section{Theory and Hypotheses}

While organizational commitment is often conceived of as a multifaceted construct, research indicates that its facets are inter-correlated to the extent that studying one overall commitment construct has import (Morrow, 1993). The present study follows the widely used conceptualization and associated measures proposed by Mowday, Steers, and Porter (1979), which characterize organizational commitment as having a strong belief in the organization's goals and values, displaying a willingness to exert extra effort, and having a strong desire to be a member of the organization. This definition captures both an individual's affective bond with the organization and behaviors that maintain organizational membership. Consistent with Schein's (1980) argument that psychological contracts are key determinants of employee attitudes and behaviors in the workplace, scholars have noted strong conceptual links between psychological contracts and organizational commitment (Sturges et al., 2005; Raja, Johns, \& Ntalianis, 2004).

\section{Psychological Contract Theory}

Psychological contracts refer to individuals' beliefs regarding the exchange agreement between themselves and the organization (Rousseau \& Tijoriwala, 1998; Rousseau, 1995). It is the individual's mental model (i.e. schema) of her/his relationship to the organization and varies in the extent to which it is transactional versus relational (Rousseau, 1995). Transactional contracts are characterized by shortterm, limited involvement with a focus on the exchange of economic resources, whereas relational contracts involve long-term, open-ended involvement and the ongoing exchange of socio-emotional resources. Transactional contracts are based upon pragmatic legitimacy, emphasizing the importance of tangible and positive outcomes for both parties. In contrast, relational contracts focus on moral legitimacy, implying an ethical obligation to do the right thing to exchange partners, regardless of short-

term outcomes. Due to the distinctions in stability (long-term, open-ended time frame versus short-term, 
closed-ended time frame) and motivation (social-emotional driven versus purely materialistic outcome driven), relational contracts have been theorized to be positively associated with organizational commitment, whereas transactional contracts are not (Bal, Kooij, \& DeJong, 2013; Rousseau, 1995).

Rousseau (1995) suggests that the signals embedded in HRM practices are a primary means for organizations to shape their employees' psychological contracts. Similarly, several HRM scholars have argued that HRM practices serve as important communications from the organization to employees regarding the organization's intentions (Bowen \& Ostroff, 2004; Guzzo \& Noonan, 1994). However, as psychological contracts reside within individuals, they are subject to individual cognitive differences in constructing meaning associated with HRM practices (Morrison \& Robinson, 1997). The cognitive theory of cultural meaning (Strauss \& Quinn, 1997) explains that an individual's interpretation process includes an identification of the meaning and expectations regarding it, and, often, a feeling about it and motivation to respond to it. Cross-cultural research (Hofstede, 2001) further argues that the interpretations of the actions of others or of institutions are widely shared among individuals with similar national cultural values (as a result of common understanding and expectations) but significantly different among individuals across cultural values. Given the strong focus on cognitive process underlying psychological contract theory and the national culture, we would expect that the interpretation of signals associated with specific HRM practices will differ across individuals in distinct national cultures, resulting in different psychological contracts. Existing research has documented significant differences in how environmental events and features impact psychological contracts across national cultures (Rousseau \& Schalk, 2000), supporting our assertion that psychological contracts are influenced to some extent by the extant cultural values.

\section{$\underline{\text { National Culture }}$}

Hofstede (2001) defined national culture as the collective programming of the mind. National culture exists within the knowledge and shared belief systems of individuals from the same nation, which are formed during childhood and reinforced throughout life (Strauss \& Quinn, 1997). As such, national 
culture tends to be stable and durable, and has a strong impact on one's cognitive process. We focus on one specific cultural dimension: institutional collectivism.

Collectivism is arguably the most studied cross-cultural value dimension in organizational behavior. While all conceptualizations of collectivism have focused on the extent to which group goals and identities are valued over individual goals and identities (Markus \& Kitayama, 1991; Erez, 1994), earlier conceptualizations of the construct defined collectivism as both unidimensional (Hofstede, 1980) and multi-dimensional (Triandis, 1994). Recent research conducted as part of the GLOBE project (House et al., 2004) supports a two-dimensional view of collectivism: institutional collectivism and in-group collectivism. The institutional collectivism measures used by the GLOBE project capture the extent to which group loyalty is emphasized at the expense of individual goals, the extent to which organizational systems emphasize collective interests as opposed to individual interests, and the extent to which being accepted by the group and group cohesion is valued and supported by organizations. In contrast, the measures for in-group collectivism gauge expectations for family attitudes and interactions (Brewer \&Venailk, 2011).

We focus on institutional collectivism because it is particularly relevant to organization-level HRM and psychological contracts. First, it specifically addresses cultural expectations for organizational practices and actions related to how one integrates with the organization. These expectations for organizational practices and actions, in turn, should influence the meanings ascribed to relevant HRM practices and, by extension, individual psychological contracts. Second, institutional collectivism's emphasis on the extent to which the self is viewed as an independent versus interdependent entity has important implications for the motives underlying the exchange relationships upon which psychological contracts are based (Markus \& Kitayama, 1991; Thomas et al., 2003).

To date, theoretical and empirical research on institutional collectivism in general and its role in the link between HRM and organizational commitment in particular is quite limited, despite its conceptual relevance. To address this gap in the literature, we draw from previous theoretical work on collectivism that is consistent with the defining principles of institutional collectivism, from the 
psychological contract literature, and from the HRM and the organizational commitment literatures to explore how institutional collectivism might moderate the effects of organization-level HRM practices on individual-level organizational commitment.

\section{$\underline{\text { Hypotheses }}$}

We examine three organization-level HRM practices: training, employee involvement in decision making, and teamwork, all of which have been linked to organizational commitment in previous strategic HRM research (Kooij, Jansen, Dikkers, \& De Lange, 2010; Snell \& Dean, 1992). These practices indicate the organization's intentions to enhance employee skills, motivation, and opportunity to contribute (Jiang, Hu, \& Baer, 2012). Moreover, these practices are also arguably culture-bound (Reiche et al., 2012) and directly relate to the extent to which employees are viewed as independent versus interdependent entities. As a result the interpretations of these practices may depend on the level of institutional collectivism in the extant culture.

\section{$\underline{\text { Training }}$}

Low collectivism cultures are characterized by an independent self. In these environments individuals' cognition tends to focus on personal needs. Thus, individuals in low institutional collectivism cultures are more likely to interpret training as an organizational investment to increase the economic benefits provided by the employee to the organization. A significant portion of the individuals' attention would be drawn to the implied economic exchange with the organization and to the immediate benefits they may personally gain, including improved marketability and better job performance, among other economic advantages. Therefore, while expected future benefits of training may be interpreted as signaling some ongoing exchange of socio-emotional benefits that would contribute towards a relational psychological contract, individuals in low institutional collectivism cultures are more likely to interpret training with a pragmatic monetary focus, formulating psychological contracts that contain a significant transactional component.

In contrast, high institutional collectivism cultures are characterized by organizations that actively promote an interdependent self-view. In this case, organizational messages conveyed through training 
would be interpreted as investments that allow individuals to be more technically and socially involved in the organization, which are both significantly valued in collectivist cultures (Erez, 1994). Individual attention would focus more on how training can improve one's contribution to the organization and align one's behaviors with organizational goals. Consequently, individuals within high institutional collectivism cultures are more likely to interpret training in relational terms, leading to more relational psychological contracts.

In the existing literature, training is often proposed to contribute to organizational commitment (Mathieu \& Zajac, 1990). However, the empirical evidence is inconclusive: Some research has found no significant relationships between training and organizational commitment in U.S.-based studies (Fiorito, Bozeman, Young, \& Meurs, 2007), while Kooij et al.’s (2010) meta-analysis found a significant correlation between training and affective commitment. We argue that the relationship between training and organizational commitment will be positive and stronger in cultures with high institutional collectivism because in these cultures perceived psychological contracts are likely be more relational, resulting in increased organizational commitment.

H1: The positive relationship between organization-level training practice and individual-level organizational commitment will be stronger in high institutional collectivism cultures than in low institutional collectivism cultures.

\section{Employee involvement in decision making}

Employee involvement in decision making is defined as the degree to which individual employees have autonomy and input surrounding the decisions that affect the organization or their work (Aiken \& Hage 1966). In low collectivism cultures, where personal needs and goals take priority over collective needs and goals, we would expect individuals to correlate high involvement in decision making with the organization's interest in their unique skills and abilities, which, in turn, would lead to an increased relational psychological contract focus and higher organizational commitment. Conversely, low involvement in decision making may seem to signal the organization's limited interest in employees' 
personal needs or unique skills, thus leading to an increased transactional psychological contract focus and lower organizational commitment.

In contrast, while high employee involvement in decision making may make employees feel valued, it could also be perceived as increasing ambiguity and undermining the consistency necessary to form a highly valued strong collective (Andreassi \& Lawter, 2014; Li et al., 2012). In high institutional collectivism cultures, reduced employee involvement is likely to be understood as a necessary part of creating a strong collective, whereby individual behavior is tightly controlled and continually directed towards common organizational goals and values (Burns \& Stalker, 1961; Pfeffer \& Selansik, 1978). By promoting consistency, low participation in decision making effectively reduces individual deviation from expected behaviors and increases collective action. Employees would be more likely to focus on this valued outcome of low decision making involvement rather than perceiving it as the organization's lack of concern for employees' social-emotional needs. Consequently, reduced employee involvement in decision making in high institutional collectivism does not necessarily result in a transactional-focused psychological contract. Compared to those in low institutional collectivist cultures, individuals in high institutional collectivism cultures are less likely to respond to high employee involvement in decision making by forming a more relational-based psychological contract; thus, the positive contribution of this practice to organizational commitment would be smaller.

Past research on the impact of employee involvement in decision making on organizational commitment is inconclusive. Some has found negative relationships between centralized decision making (i.e., low employee involvement in decision making) systems and organizational commitment (Fiorito et al., 2007; Lincoln \& Kalleberg, 1985), while others have found positive correlations between high employee involvement in decision making processes and organizational commitment in U.S. samples (Florkowski \& Schuster, 1992). We extend this line of work by arguing that the positive relationship between employee involvement in decision making and individual organizational commitment is weaker in high institutional collectivism cultures than in low institutional collectivism cultures. 
H2: The positive relationship between organization-level employee involvement in decision making practice and individual-level organizational commitment will be weaker in high institutional collectivism cultures than in low institutional collectivism cultures.

\section{Teamwork}

Teamwork is highly consistent with the interdependent view of the self that helps to define collectivism (Hofstede, 1980; Markus \& Kitayama, 1991). Those with an interdependent self-view would interpret teamwork as an organization's investment in shared resources that allow individuals to build strong group cohesion and group membership, which are both strongly emphasized by institutional collectivism (Gelfand et al., 2004). Moreover, institutional collectivism is associated with the cultural endorsement of team-oriented leadership (Gelfand et al., 2004), so managers attempting to implement teamwork-focused HRM practices would likely be favorably noticed and received in high institutional collectivism cultures. In return, individuals in these cultures are motivated to create long-term moral obligations by keeping relationships open and dynamic (Yang, 1993). Overall, teamwork in high collectivist cultures is likely to be interpreted as a long-term commitment to integrating the employee with the organization, and would likely emphasize relational psychological contracts and higher levels of organizational commitment.

Conversely, in low institutional collectivism cultures, individuals are more likely to value their independent individual identity over their team identity (Hofstede, 1980; Markus \& Kitayama, 1991). In these cultures, teamwork would more likely be interpreted as the organization's attempt to boost its own success through the increased sharing of individual ideas and unique resources (Lawler, 1991). This practice is less likely to be seen as a reflection of the employee's value within a greater collective. Thus, the implications of social-emotional relationships associated with teamwork would receive less emphasis than in collective cultures, resulting in correspondingly lower levels of relational psychological contracts and a weaker contribution to organizational commitment.

Kooji et al.’s (2010) meta-analysis reported a significant, positive relationship between teamwork and commitment. We further argue that teamwork would be more strongly related to organizational 
commitment in high institutional collectivism cultures than in low institutional collectivism cultures as we expect that individuals would form stronger relational contracts in high institutional collectivism cultures.

H3: The positive relationship between the organization-level teamwork practice and individual level organizational commitment will be stronger in high institutional collectivism cultures than in low institutional collectivism cultures.

\section{Methods}

The data used for empirical analysis came from Round Three of the High Performance Manufacturing (HPM) study, which is the third phase of the World Class Manufacturing project (Flynn, Schroeder, \& Sakakibara, 1994; Schroeder \& Flynn, 2001). Data from the organizations included in the present study was collected during 2005-2006 by a team of researchers in North America, Europe, and Asia. As detailed in Table 1, the HPM dataset used for our research included 120 mid- to large-sized manufacturing plants (each with at least 250 employees) located in four countries (Japan, Sweden, Austria, and Germany) across three industries (electronics, machinery, and auto supply). As described below, we tested our hypotheses using multi-level analyses with HRM practices at the plant level and organizational commitment at the individual level. Overall the dataset included 2,424 respondents from four distinct job classifications (direct labor, human resource manager, supervisor, plant superintendent). Measures for the HRM practices were formed by aggregating the responses from three to 14 respondents per plant, with respondents for each measure representing at least three different job classes (Appendix A). Statistical analyses of inter-rater reliability indices (reported in Table 2) supported this aggregation. Organizational commitment data was collected from 1,191 individuals from three different job classifications, for an average of about 9.9 individuals per plant.

The HPM study employed a rigorous translation procedure. Originally developed in English, the foreign-language versions of the surveys were back-translated by multiple translators and compared for accuracy. Additionally, all survey instruments were initially pilot-tested through structured interviews with manufacturing employees, and then extensively tested and refined using large scale data in the prior rounds of the project (Ahmad \& Schroeder, 2003; Noar, Goldstein, Linderman, \& Schroeder, 2008). 
Reliability and validity of the included measures have been well-established in the existing literature (Roth, Schroeder, Huang, \& Kristal, 2008).

Insert Table 1 about here

Surveys were administered to only one plant per manufacturing organization. Data were collected on site by managers who had at least three years of work experience in the plants and were knowledgeable about the major responsibilities of the employees working in the plants. A packet of 21 questionnaires containing different sets of measures was distributed and answered by 11 different managers and 10 workers/supervisors at each of the $\mathrm{x} \#$ of participating plants. These 21 individual respondents came from different parts of the plant at each facility. Of these, the response rate was approximately $65 \%$.

We conducted reliability analysis to ensure internal consistency of the scale items across informants for each of the HRM measures. We used inter-rater agreement statistics $R_{w g}$ and intraclass correlation (ICC) statistics to measure the degree of agreement on the scale ratings among informants within the same plant. As shown in Table 2, all of our constructs had $R_{w g}$ and ICC values above 0.70 , indicating that the instruments exhibit acceptable agreement and justifying aggregation of the HRM measures at the plant level.

\section{$\underline{\text { Measures }}$}

Employee training, employee involvement in decision making, and teamwork were measured using multiple items contained in the HPM database. For each item, respondents indicated the extent to which they agreed or disagreed with the statement on a seven-point Likert scale ranging from strongly disagree (1) to strongly agree (7). A complete list of the items used for each measure is presented in Table 2.

Employee training. Employee training was measured using four items $(\alpha=.85)$ that asked the extent to which ongoing training was emphasized and delivered. A sample item included "Our employees 
regularly receive training to improve their skills." This scale has shown to be valid and reliable in previous research (Liu, Shah, \& Schroeder, 2006; Phan, Abdallah, Matsui, 2011).

Employee involvement in decision making. Employee involvement in decision making was measured with three items $(\alpha=.87)$ taken from Aiken and Hage's (1966) five-item centralization of decision making scale. A sample item read "Any decision I make has to have my boss's approval." All items were reverse coded to reflect our focus on employee involvement in decision making. This measure has demonstrated to be valid and reliable in previous research (Huang, Kristal, \& Schroeder, 2008).

Teamwork. Teamwork was measured using three items $(\alpha=.85)$ focusing on the extent to which supervisors encouraged their subordinates to exchange ideas and work as a team. A sample item was "Our supervisors encourage the people who work for them to work as a team." This measure has demonstrated to be valid and reliable in previous research (Huang et al., 2008).

Organizational Commitment. Organizational commitment was measured using six items $(\alpha=.92)$ from the nine-item short version of the Organizational Commitment Scale (OCQ) developed by Mowday, Steers, and Porter (1979). A sample item was "For me, this is the best of all organizations for which to work." The OCQ is widely used, and research has demonstrated the reliability and validity of the short version of the scale (Huselid \& Day, 1991; Kirchmeyer, 1992).

We included control measures related to plant size, industry, respondent job type (supervisor/ direct labor), and country. Plant size was measured as the sum of the number of hourly and regular salaried employees reported in each plant (Cua, McKone, \& Schroeder, 2001). We replaced missing values for seven cases with the mean size of the plants in the sample in the same country. We performed a natural $\log$ transformation on this variable to adjust for skewness. We created dummy variables for electronics and auto suppliers industries to control for industry effects. We also included a dummy variable indicating whether the respondent of the organizational commitment measure was direct labor or supervisory (direct labor $=0$, area or plant supervisor $=1$ ). We included a dummy variable to control for country-level effects in each of the two subgroups utilized in the analyses described below (Germany $=1$, 
Austria $=0$; and Japan =1, Sweden =0). Finally, we note that while other control variables such as employee tenure would have been useful, we were limited to the measures included in the HPM dataset. We performed a confirmatory factor analysis (CFA) to assess the validity of the Level 2 (i.e. the plant level) latent variables (Andersen \& Gerbing, 1988). Overall, the three-factor CFA model resulted in an acceptable fit to the data; $\chi^{2}(31)=38.45(p=.18)$, GFI $=.94, \mathrm{CFI}=.98, \mathrm{RMSEA}=.05$. As shown in Table 2, item loadings were all greater than 0.50 , and the critical ratio for each loading is significant, indicating convergent validity (Andersen \& Gerbing, 1988). The average variance explained (AVE) across the indicators of each latent variable was higher than the variance shared by any two latent variables, thereby passing a stringent test of discriminant validity among the latent variables (Fornell \& Larcker, 1981).

Insert Table 2 about here

\section{Results}

Consistent with the recommendation from other empiricists on cultures (Hofstede, 2006; Brewer \& Venaik, 2011), we created two subsamples using institutional collectivism practice scores from the GLOBE study; one ranked high on this culture dimension (Japan and Sweden), and the other ranked significantly lower than those in the high subgroup (Austria and Germany). We used the "as is" scores rather than the "should be" institutional collectivism scores because the former captured current perceptions of the level of institutional collectivism in the country in question, as opposed to reflecting future institutional collectivism goals and aspirations (Brewer \& Venaik, 2011). Combining countries in this manner provided two distinct advantages. First, it provided adequate statistical power to include all of the control variables and independent variables in a single regression model, which would not have been possible with single country analyses. Second, the countries included in each of the subgroups differed from each other on several other cultural dimensions, which provided greater confidence that any observed differences were the result of institutional collectivism rather than other cultural factors. Specifically, based on current practice scores, the GLOBE study placed Japan and Sweden in different 
statistical bands in five of the eight remaining cultural dimensions, and Germany and Austria in different bands in four of the eight remaining dimensions. In only one other instance (assertiveness) did the countries included in our study display groupings similar to institutional collectivism.

To test our hypotheses, we utilized hierarchical linear modeling (HLM; Raudenbush \& Byrk, 2002) on the two subsamples. All independent variables were modeled as Level 2 predictors of the Level 1 intercept except for direct labor, which was modeled as a Level 1 variable. Raw (non-centered) data was used for all Level 1 variables, and all Level 2 variables were grand mean centered.

\section{Insert Tables 3 and 4 about here}

Variable means, standard deviations, and intercorrelations are shown in Table 3. Comparative hypotheses were tested by examining the difference between the regression coefficient estimates for the Level 2 predictors of the Level 1 intercept associated with high and low institutional collectivism subsamples, following the procedure described by Cohen (1983). As shown in Table 4, training was significantly related to organizational commitment in the high institutional collectivism sample $(\gamma=.31, p$ $\leq .01)$ but not in the low institutional collectivism sample. The difference between the regression coefficients was significant $(z=4.01, p \leq .01)$. These results indicate the moderating effect of national cultures on the relationship between training and individual organizational commitment, and provide partial support to Hypothesis 1. Employee involvement in decision making was significantly related to organizational commitment in the low institutional collectivism sample $(\gamma=.24, p \leq .05)$ but was not in the high institutional collectivism sample. The difference in the regression coefficients between the two samples was marginally significant $(z=1.34, p \leq .10)$. These results provide some, but not full, support for Hypothesis 2, which proposed that the positive impact of employee involvement in decision making on organizational commitment would be reduced in high institutionalism collectivism cultures. Finally, teamwork was a significant predictor in both samples $(\gamma=.42, p \leq .01$ for low institutional collectivism, and $\gamma=.56, p \leq .01$ for high institutional collectivism). The difference between the regression coefficients was significant $(\mathrm{z}=1.60, p \leq .05)$, supporting Hypothesis 3 . 


\section{Discussion}

Overall we found empirical support for the moderating effects of culture for all three HRM practices. This finding is consistent with the contingency perspective of HRM (Alcazar, Fernandez, \& Gardey, 2011), which states that the effectiveness of HRM systems depends on contextual factors that affect employee interpretations of the various HRM practices in the system (Bellou, 2007). Our results also supported the GLOBE's contention that institutional collectivism represents a theoretically and empirically useful construct in comparative research, especially for research questions involving organizational policies and procedures. One particularly interesting outcome of this perspective was the consideration of Japan and Sweden as culturally similar countries, which is not typical in cross-cultural research. Moreover, the regression coefficients associated with country dummy control variables were not significant in either of our HLM models, providing indirect support that institutional collectivism was the significant factor in explaining the difference between groups rather than other cross-cultural values that varied between the countries in the group.

Our argument that national culture is a significant source of variation among individuals' perceptions of HRM practices (Bellou, 2007) was based on psychological contract theory (Rousseau, 1995). Rousseau and Schalk (2000) proposed that the underlying building blocks of psychological contracts: the meaning of the promise, perceptions of uncertainty, and beliefs regarding the future and time, may vary across national cultures. Specifically, researchers have suggested that in addition to collectivism, the cultural values of power distance, uncertainty avoidance, and future orientation may affect processes related to these building blocks (Rousseau, 2000; Rousseau and Schalk, 2000; Sparrow, 1998; Thomas et al., 2003). While we grouped the countries in our study according to their institutional collectivism scores, there were no similar grouping patterns for the other three dimensions listed above. All four countries placed in the same statistical band of power distance, and three of the four countries

placed in the same band in each of the other two dimensions. This research design allowed us to focus on institutional collectivism while controlling, to a certain extent, variations in other relevant culture 
dimensions, further highlighting the potential significance of institutional collectivism in cross-cultural research focusing on individual differences.

Our results also found differences in the moderation pattern across the three HRM practices included in our study. While teamwork had significant effects in both low and high institutional collective cultures, the effects of training and employee involvement in decision making were not significant in one of the cultural groups. This suggests that the moderating roles of national culture on the effectiveness of the latter two HRM practices may be even stronger than we hypothesized. One possible explanation is that training in low institutional collectivism cultures and employee involvement in decision making in high institutional collectivism cultures operate as hygiene factors (Sparrow, 1998). When they were not present, employees would be demotivated to form a relational psychological contract, but once present at a threshold level, any further improvements were not associated with a linear increase in relational psychological contract focus. This may be particularly true in the case of training in low collectivism cultures, where we believe individuals tend to view training from an economic/ transactional perspective.

However, further consideration of the multi-level nature of the data provides a possible alternative explanation of some of these results. Psychological contracts reside within individuals and are subject to individual cognitive differences (Morrison \& Robinson, 1997). While national culture exists within the knowledge and shared belief systems of individuals from the same nation (Thomas et al., 2003; Triandis, 1995), the consistency of the shared interpretations may vary among distinct HRM practices in two cultural groups.

Bowen and Ostroff (2004) proposed that how HRM systems are implemented, that is, the process of HRM, can influence the construction of shared understandings among employees. Differences in the implementation of training and employee involvement in decision making programs may have important implications, depending on the national culture. For example, the implementation of employee involvement in decision making can vary on a number of dimensions, including process (i.e., consensus, votes with open or closed ballets) and the individuals involved (employees at the same level or at mixed 
levels). High collectivist cultures tend to emphasize these contextual issues more than low collectivist cultures (Markus, \& Kitayama, 1991), and as a result, variations in the implementation of employee involvement in decision making will result in greater variations at the individual level, and an overall weaker relationship between this practice and individual level outcomes. On the other hand, individuals in low collectivism cultures will place less meaning on these process/ contextual issues, focusing primarily on the extent to which one is involved in the decision making process. This perspective would also help explain the full support of our hypotheses related to teamwork. Even though the exact form may differ, the implementation of teamwork is less likely to send ambiguous signals. Teamwork requires constant communication, coordination, and adaptation, and the resulting group sense making and cohesion should minimize individual variation in interpretations of the practice (Wright \& Nishii, 2013). Theoretical Implications

Our research has several theoretical implications. First, previous cross-cultural comparative HRM research has primarily focused on documenting differences in HRM practices across nations (Reiche et al., 2012). We extend this research by empirically examining the effects of HRM practices on a central employee outcome, organizational commitment. In doing so, we integrated the macro-level strategic HRM literature with individual-level organizational behavior theory and psychological contract theory. This approach allowed us to propose possible mechanisms through which culture may influence individuals' perception of and subsequent reaction to organizational-level HRM practices. Our dataset allowed us to test our proposed relationships with an empirical analysis that explored variances on three different levels in one study, consistent with recent scholarship noting the importance of multi-level analyses to HRM research (Bal et al., 2013; Bowen \& Ostroff, 2004; Wright \& Nishii, 2013). Moreover, our multi-level analyses allowed us to include individual-level variables that may affect the relationship in question. For example, we were able to control for the effects of organizational position, which would not have been possible with aggregate outcomes measures.

Our research also has important implications for the comparative psychological contract literature. The anthropological and psychological schools of thought dominate research on cross-national 
differences in psychological contract (Rousseau \& Schalk, 2000). The anthropological view argues that national cultural differences are so fundamental and pervasive that the nature and forms of psychological contracts are culture-specific, while the psychological view posits that human cognitive processes are universal and adaptable, and therefore the nature and forms of psychological contracts are generalizable. Sparrow (1998) developed a socio-cognitive framework that included factors from each perspective and emphasized the impact environmental factors exert on various psychological contract processes.

Similarly, Hui, Lee, \& Rousseau (2004) argue that more research is needed to determine the extent to which the psychological mechanisms related to psychological contracts are consistent across cultures. Our research departs from existing research that examines the distinctiveness of psychological contracts in different societies. (Rousseau \& Schalk, 2000). Instead, we echo Sparrow's conceptualization by focusing on how differences in national cultural affect the formation of individual psychological contracts resulting from implicit communications embedded in HRM practices.

With few exceptions (Hui et al., 2004), most empirical cross-cultural psychological contract research has focused on understanding psychological contract violations, and how employee responses to perceived fulfillment and violations of psychological contracts vary across cultures (Epitropaki, 2013). Scholarship investigating cultural influences on psychological contract formation and its relation to employee behaviors has relied on either conceptual arguments (Sparrow, 1998; Thomas et al., 2003) or empirical studies conducted in one society (Hui et al., 2004; Rousseau \& Schalk, 2000). Few empirical research studies have examined the relationships among psychological contracts with individual-level outcomes across cultures. Towards this end we have made an important contribution. While we did not include direct psychological contract measures, our results were consistent with the notion that relational and transactional psychological contracts have similar influence on organizational commitment across cultures. More comparative research that includes direct measures of psychological contracts is needed to substantiate our findings and provide additional significant insights to cross-cultural HRM phenomena.

\section{$\underline{\text { Managerial Relevance }}$}


Our results also have several implications for managers looking to increase employee commitment in cross-cultural or multi-national organizations. While the focus of this paper was on HRM practices, the results have practical implications for both HRM and line level managers, given that line level managers can have considerable latitude in HRM-practice implementation. First, most research on the effects of HRM practices has relied on samples from countries with moderate or low institutional collectivism ratings, such as the United States. Our results indicate that HRM practices that the extant literature has revealed to facilitate organizational commitment may have greater or weaker effects on organizational commitment in organizations operating in other cultures. For example, both training and teamwork appear to result in higher levels of organizational commitment in high institutional collectivism cultures, indicating that implementing these practices in high institutional collectivism cultures may yield benefits beyond increased job expertise and knowledge sharing.

In contrast, our results further suggest that the negative effects of policies that decrease employee autonomy, such as lower levels of decision making involvement, are less likely to result in lower organizational commitment in high institutional collectivism cultures than the literature would suggest. By extension, it appears that HRM practices designed to increase employee autonomy and decision making responsibility may not yield the positive effects on organizational commitment generally expected by HRM managers operating in the United States and similar countries. Finally, although the present study did not include a full array of HRM practices, all of the included practices have been identified as integral components of high commitment HRM systems. Given the differential effects observed across the three HRM practices in the present study, our results suggest that that universal application across cultures of high-commitment HRM bundles, as they are currently conceptualized, may be premature. However, additional research is needed to understand exactly how high-commitment HRM bundles may vary across cultures.

\section{Limitations, Future Research, and Conclusions}

Our study has several limitations that should be noted. First, it utilized cross-sectional data; thus, we cannot make definitive conclusions regarding causality. Perhaps more importantly, we do not capture 
the temporal elements associated with psychological contracts and organizational commitment, both of which develop as a result of accumulated experiences over time (Rousseau, 1995). A natural direction for future longitudinal research would be to allow a direct test of the casual relationships hypothesized in this research. Longitudinal research could also examine the extent to which the effectiveness of HRM practices is stable over time and whether any differences in stability are associated with cultural variations. Second, while attempts were made to gather data from a wide variety of firms and the participating companies were strategically chosen to provide a balanced sample in terms of industries and plant performance, the sample consisted only of manufacturing organizations in a limited set of industries. Future research is needed to determine if our results are generalizable to service or other industries.

Third, we relied on national culture to test our hypotheses and did not take into account differences at the organizational level, such as organizational culture or HRM implementation processes, that could have impacted the results. At the organizational level, we mitigated this limitation by a certain extent through our HLM analyses, but we did not include specific measures related to these concepts. Future research that better models of these variations would illuminate how various levels of cultural environments interact to impact the effectiveness of HRM practices. Moreover, we used national culture as a theoretical lens to interpret the results but did not explicitly measure national culture. Thus, our analysis and conclusions are contingent upon the validity of the underlying cultural models. A direct measure of culture in future research would both decrease our reliance on culture scores reported in other studies and increase the range of cultural variations present in the sample to enable a stronger analysis of the moderating effects of national cultures.

Additionally, while our institutional collectivism grouping allowed us to indirectly control for the other cultural values identified by the GLOBE study, the culture scores of assertiveness would have resulted in similar country groups used in the present study (with high and low reversed). Conceptually, assertiveness is less relevant to this study, as it does not explicitly address cultural expectations for organizational practices. We were able instead to develop strong theoretical arguments for the moderating 
effects of institutional collectivism. However, future research should examine the role of assertiveness, as our methodology was not able to empirically rule out this variable as having an impact on our results.

Finally, the GLOBE project provides data on current practices and values. The practices are based on questions that asked respondents about their current "as is" states, while the values scores are based on questions that asked respondents how things "should be." We grouped our countries using current practice scores of institutional collectivism, arguing that this was more relevant to our theoretical arguments than desired "should be" states. However, the GLOBE study provides little guidance regarding the practical application and uses of the two measures, and there are often significant differences between the two. Indeed, in our sample, only Austria had similar practices and values scores for institutional collectivism. Research taking a different perspective on the applicability of the current practices versus values measures would likely produce different results. Future research needs to address this issue.

Still, these limitations notwithstanding, our results provide empirical support for the notion that the forces that bond individual workers to their work organizations vary significantly across cultures in ways that have both theoretical and practical relevance to HRM policy. We hope that our study opens the door to further research on this important phenomenon. 


\section{References}

Abramson, N., Keating, R., \& Lane, H.W. (1996). Cross-national cognitive process differences: A comparison of Canadian, American and Japanese Managers. Management International Review, 36, $123-148$.

Ahmad, S., \& Schroeder, R. G. (2003). The impact of human resource management practices on operational performance: Recognizing country and industry differences. Journal of Operations Management, 21, 19-43.

Aiken, M., \& Hage, J. (1966). Organizational alienation: A comparative analysis. American Sociological Review, 31, 497-507.

Alcazar, F.M., Fernandez, P.M.R., \& Gardey, G.S. (2011). Workforce diversity in strategic human resource management models: A critical review of the literature and implications for future research. Cross-Cultural Management, 20(1), 39-49.

Althauser, R. P. (1989). Internal labor markets. Annual Review of Sociology, 143-161.

Amanthram, S., \& Chan, C. (2013). Challenges and strategies for global HR executives: Perspectives from Canada and the U.S. European Management Journal, 31, 223-233.

Andersen, J.C., \& Gerbing, D.W. (1988). Structural equation modeling in practice: A review and recommended two-stop approach. Psychological Bulletin, 103, 411-423.

Andreassi, J.K., \& Lawter, L. (2014). Cultural impact of human resource practices on job satisfaction: A global study across 48 countries. Cross-Cultural Management, 21(1), 55-77.

Arthur, J. B. (1994). Effects of human resource systems on manufacturing performance and turnover. Academy of Management Journal, 37(3), 670-687.

Aycan, Z. (2005). The interplay between cultural and institutional / structural contingencies in human resource management, International Journal of Human Resource Management, 16(7), 1083-1119. 
Aycan, Z., Kanungo, R.N., Mendonca, M., Yu, K., Deller, J., Stahl, G., \& Khursid, A. (2000). Impact of culture on human resource management practices: A ten country comparison. Applied Psychology: An International Review, 49 (1), 192-220.

Bal, P.M., Kooij, D.T.A., \& De Jong, S. B. (2013). How do developmental and accommodative HRM enhance employee engagement and commitment? The role of psychological contract and SOC strategies. Journal of Management Studies, 50(4), 545-572.

Bellou, V. (2007). Identifying employees' perceptions on organizational obligations: A comparison between the Greek public and private sector. International Journal of Public Sector Management, 20(7), 608-621.

Blau, P. M. (1964). Exchange and power in social life. Transaction Publishers.

Boselie, P., Dietz, G., \& Boon, C. (2005). Commonalities and contradictions in HRM and performance research. Human Resource Management Journal, 15(3), 67-94.

Bowen, D. E., Galang, C., \& Pillai, R. (2002). The role of human resource management: An exploratory study of cross-country variance. Human Resource Management, 41(1), 103-122.

Bowen, D. E., \& Ostroff, C. (2004). Understanding HRM-Firm performance linkages: The role of the “strength" of the HRM system. Academy of Management Review, 29(1), 203-221.

Brewer, P., \& Venaik, S. (2011). Individualism - Collectivism in Hofstede and GLOBE, Journal of International Business Studies, 42(3), 436-445.

Brewster, C., \& Mayrhofer, W. (Eds.) (2012). Handbook of Research on Comparative Human Resource Management. Cheltenham, UK: Edward Elgar Publishing Limited.

Brief, A. P. (1998). Attitudes In and Around Organizations, (Vol. 9). City, ST: Sage.

Budhwar, P.S., \& Sparrow, P.R. (2002). Strategic HRM through the cultural looking glass: mapping the cognition of British and Indian managers. Organization Studies, 23(4), 599-638.

Burns, T., \& Stalker, G. (1961). The Management of Innovation. London, UK: Tavistock. 
Caliguiri, P. (2014). Many moving parts: Factors influencing the effectiveness of HRM practices designed to improve knowledge transfer within multinational corporations. Journal of International Business Studies, 45, 63-72.

Chang, E. (2005). Employees' overall perception of HRM effectiveness. Human Relations, 58(4), 523 544.

Cohen, A. (1983). Comparing regression coefficients across subsamples: A study of the statistical test. Sociological Methods and Research, 12, 77-94.

Combs, J., Liu, Y., Hall, A., \& Ketchen, D. (2006). How much do high-performance work practices matter? A meta-analysis of their effects on organizational performance. Personnel Psychology, 59(3), 501-528.

Cua, K. O., McKone, K. E., \& Schroeder, R. G. (2001). Relationships between implementation of TQM, JIT, and TPM and manufacturing performance. Journal of Operations Management, 19(6), 675-694.

Dorfman, P.W., Hanges, P.L., \& Brokbeck, F.C. (2004). Leadership and cultural variation: The identification of culturally endorsed leadership profiles. In R.J. House, P.J. House, J. Hanges, P.W. Mansour, Dorfman, \& V. Gupta (Eds.) page numbers needed here Culture, Leadership and Organizations. Thousand Oaks, CA: Sage.

Eccles, T. (1993). The deceptive allure of empowerment. Long Range Planning, 26(6), 13-21.

Eisenberger, R., Huntington, R., Hutchiston, S., \& Sowa, D. 1986. Accounting for organizational citizenship behavior: Leader fairness and task acope versus satisfaction. Journal of Management, 16, 705-722.

Epitropaki, O. (2013). A multi-level investigation of psychological contract breach and organizational identification through the lens of perceived organizational membership: Testing a moderatedmediated model. Journal of Organizational Behavior 34: 65-86.

Erez, M. (1994). Towards a model of cross-cultural I/O psychology. Handbook of Industrial and Organizational Psychology, 4, 569-607. 
Fey, C.F. (2005). Opening the black box of motivation: A cross-cultural comparison of Sweden and Russia. International Business Review, 14(3): 345-367.

Fey, C.F., \& D. R. Denison. (2003). Organizational culture and effectiveness: can American theory be applied in Russia? Organization Science, 14(6): 686-706.

Fiorito, J., Bozeman, D. P., Young, A., \& Meurs, J. A. (2007). Organizational commitment, human resource practices, and organizational characteristics. Journal of Managerial Issues, 186-207.

Fisher, R., \& Mansell, A. (2009). Commitment across cultures: A meta-analytical approach. Journal of International Business Studies, 40, 1339-1358.

Fiske, S., \& Taylor, S. (1984). Social Cognition. Reading, MA: Addison-Wesley.

Florkowski, G. W., \& Schuster, M. H. (1992). Support for profit sharing and organizational commitment: A path analysis. Human Relations, 45(5), 507-523.

Flynn, B.B., Schroeder, R.G., \& Sakakibara, S. (1994). A framework for quality management research and an associated measurement instrument. Journal of Operations Management, 11 (4), 339-366.

Fornell, C., \& Larcker, D.F. (1981). Evaluation structural equation models with unobservable variables and measurement error. Journal of Marketing Research, 1981, 18, 39-50.

Gelfand, M.J., Bhawuk, D.S, Nishii, L.H., \& Bechtold, D.J. (2004). Individualism and collectivism. In R.J. House, P.J. House, J. Hanges, P.W. Mansour, Dorfman, \& V. Gupta (Eds.) Culture, Leadership and Organizations. Page numbers needed here Thousand Oaks, CA: Sage.

Gerhart, B. (2012). Construct validity, causality, and policy recommendations: The case of high performance work practice systems. Human Resource Management Review, 22(2), 157-160.

Gong, Y., Law, K. S., Chang, S., \& Xin, K. R. (2009). Human resources management and firm performance: The differential role of managerial affective and continuance commitment. Journal of Applied Psychology, 94(1), 263-?. 
Guest, D. (1992). Employee commitment and control. In J.F. Hartley \& G.M. Stephenson (Eds.)

Employment Relations: The Psychology of Influence and Control at Work. page numbers needed here Oxford, England: Blackwell Publishers, Inc.

Gupta, V., \& Hanges, P.J. (2004). Regional and climate clustering of societal cultures. In R.J. House, P.J. House, J. Hanges, P.W. Mansour, Dorfman, \& V. Gupta (Eds.) Culture, Leadership and Organizations. Page numbers needed here Thousand Oaks, CA: Sage.

Guzzo, R. A., \& Noonan, K. A. (1994). Human resource practices as communications and the psychological contract. Human Resource Management, 33(3), 447-462.

Hackman, J. R., \& Oldham, G. R. (1975). Development of the job diagnostic survey. Journal of Applied Psychology, 60(2), 159-?.

Hackman, J. R., \& Oldham, G. R. (1976). Motivation through the design of work: Test of a theory. Organizational Behavior and Human Performance, 16(2), 250-279.

Hofstede, G. (1980). Culture's Consequences: International Differences in Work-related Values. Thousand Oaks, CA: Sage.

Hofstede, G. (1983). The cultural relativity of organizational practices and theories. Journal of International Business Studies, 14(2), 75-89.

Hofstede, G. (1993). Cultural constraints in management theories. Academy of Management Executive, 7, $81-94$.

Hofstede, G. (2006). What did GLOBE really measure? Researchers'minds versus respondents' minds. Journal of International Business Studies, 37, 882-896.

Hogg, M., \& Abrams, D. Towards a single-process uncertainly-reduction model of social motivation in groups. In M. Hogg and D. Abrams (Eds.). Group Motivation: Social Psychological Perspectives. Pages needed here New York, NY: Harvester-Wheatsheaf. 
House, R.J., Hanges, P.J., Javidan, M., Dorfman, P.W., \& Gupta, V. (2004). Culture, Leadership, and Organizations: The GLOBE Study of 62 Societies. London: Sage.

Hrebiniak, L. G., \& Alutto, J. A. (1972). Personal and role-related factors in the development of organizational commitment. Administrative Science Quarterly, 555-573.

Huang, X., Kristal, M., \& Schroeder, R. (2008). Linking learning and effective process implementation to mass customization capability. Journal of Operations Management, 26, 714-729.

Hui, C., Lee., C., \& Rousseau, D. M. (2004). Psychological contract and organizational citizenship behavior in China: Investigating generalizability and instrumentality. Journal of Applied Psychology, $89(2), 311-321$.

Huselid, M. A., \& Day, N. E. (1991). Organizational commitment, job involvement, and turnover: A substantive and methodological analysis. Journal of Applied Psychology, 76(3), 380-?.

Jiang, K., Hu, J., \& Baer, J. (2012). How does human resource management influence organizational outcome? A meta-analytic investigation of mediating mechanisms. Academy of Management Journal, 55(6), 1264-1294.

Kashima, Y., \& Callan, V. J. (1994). The Japanese work group. Handbook of Industrial and Organizational Psychology, 4, 609-646.

Kirchmeyer, C. (1992). Nonwork participation and work attitudes: A test of scarcity vs. expansion models of personal resources. Human Relations, 45(8), 775-795.

Kooij, D. T., Jansen, P. G., Dikkers, J. S., \& De Lange, A. H. (2010). The influence of age on the associations between HR practices and both affective commitment and job satisfaction: A metaanalysis. Journal of Organizational Behavior, 31(8), 1111-1136.

Kozlowski, S. W., \& Doherty, M. L. (1989). Integration of climate and leadership: Examination of a neglected issue. Journal of Applied Psychology, 74, 546-553.

Lawler, E.E. (1991). High-involvement Management. San Francisco, CA: Jossey-Bass. 
Levinson, H. (1965). Reciprocation: The relationship between man and organization. Administrative Science Quarterly, 9(4), 370-390.

Liao, H., Toya, K., Lepak, D. P., \& Hong, Y. (2009) Do they see eye to eye? Management and employee perspectives of high-performance work systems and influence processes on service quality. Journal of Applied Psychology, 94, 371-391.

Lincoln, J. R., \& Kalleberg, A. L. (1985). Work organization and workforce commitment: A study of plants and employees in the US and Japan. American Sociological Review, 738-760.

Liu, G., Shah, R., \& Schroeder, R. G. (2006). Linking work design to mass customization: A sociotechnical systems perspective. Decision Sciences, 37, 519-545.

Markus, H. R., \& Kitayama, S. (1991). Culture and the self: Implications for cognition, emotion, and motivation. Psychological review, 98(2), 224-?.

Mathieu, J. E., \& Zajac, D. M. (1990). A review and meta-analysis of the antecedents, correlates, and consequences of organizational commitment. Psychological bulletin, 108(2), 171-?.

Meyer, J. P., Stanley, D. J., Jackson, T. A., McInnis, K. J., Maltin, E. R., \& Sheppard, L. (2012). Affective, normative, and continuance commitment levels across cultures: A meta-analysis. Journal of Vocational Behavior, 80(2), 225-245.

Michailova, S., and V. Worm. (2003). Personal networking in Russia and China: Blat and Guanxi. European Management Journal, 21(4): 509-519.

Mignonac, K., Herrbach, O., \& Guerrero, S. (2006). The interactive effects of perceived external prestige and need for organizational identification on turnover intentions. Journal of Vocational Behavior, $69(3), 477-493$.

Miller, J. G., Bersoff, D. M., \& Harwood, R. I. (1990). Perception of social responsibilities in India and the United States: Moral imperatives or personal decisions. Journal of Personality and Social Psychology, 58, 33-47. 
Morrison, E. W., \& Robinson, S.L. (1997). When employees feel betrayed: A model of how psychological contract violation develops. Academy of Management Review, 22, 226-256.

Morrow, P. C. (1993). The Theory and Measurement of Work Commitment. Greenwich, CT: JAI Press.

Mowday, R. T., Porter, L. W., \& Steers, R. M. (1982). Employee-organization linkages: The Psychology of Commitment, Absenteeism, and Turnover (Vol. 153). New York, NY: Academic Press.

Mowday, R. T., Steers, R. M., \& Porter, L. W. (1979). The measurement of organizational comm

Muchinsky, P. M. (2000). Emotions in the workplace: The neglect of organizational behavior. Journal of Organizational Behavior. Issue/volume/pages needed.

Neter, J., Kutner, M.H., Nachtsheim, C.J., \&Wasserman, W. (1996). Applied Linear Statistical Models. Boston, MA: McGraw-Hill.

Nishii, L. H., Lepak, D. P., \& Schneider, B. (2008). Employee attributions of the "why" of HR practices: Their effects of employee attitudes and behaviors, and customer satisfaction. Personnel Psychology, $61,503-545$.

Noar, M., Goldstein, S.M., Linderman, K.W., \& Schroeder, R.G. (2008). The role of culture as driver of quality management and performance: Infrastructure versus core quality practices. Decision Sciences, $39,671-702$.

Ogilvie, J.R. (1987). The role of human resources management practices in predicting organizational commitment. Group and Organization Studies, 11(4), 335-359.

Phan, A.C., Abdallah, A.B., \& Matsui, Y. (2011). Quality management practices and competitive performance: Empirical evidence from Japanese manufacturing companies. International Journal of Production Economics, 133, 518-529.

Pfeffer, J., \& Slancik, G. (1978). The External Control of Organizations. New York, NY. Harper and Row. 
Peretz, H., \& Rosenblatt, Z. (2011). The role of societal cultural practices in organizational investment in training: A comparative study in 21 countries. Journal of Cross-Cultural Psychology, 42, 817-831.

Raja, U., Johns, G., \& Ntalianis, F. (2004). The impact of personality on psychological contracts. Academy of Management Journal, 47(3), 350-367.

Raudenbush, S. W., \& Bryk, A. S. (2002). Hierarchical linear models: Applications and data analysis methods. Thousand Oaks, CA: Sage Publications.

Reiche, B. S., Lee, Y., \& Quintanilla, J. (2012). Cultural perspectives on comparative HRM. In C. Brewster \& W. Mayrhofer (Eds.) Handbook of Research on Comparative Human Resource Management (pp. 51-68). Cheltenham, UK: Edward Elgar Publishing Limited.

Richter, A. W., Hirst, G., van Knippenberg, D., \& Baer, M. (2012). Creative self-efficacy and individual creativity in team contexts: Cross-level interactions with team informational resources. Journal of Applied Psychology, 97(6), 1282-?.

Roth, A. V., Schroeder, R.G., Huang, X., \& Kristal, M. M. (2008). Handbook of Metrics for Research in Operations Management: Multi-item Measurement Scales and Objective Items. Los Angeles, CA: Sage Publications, Inc.

Rousseau, D. M. (1995). Psychological Contracts in Organizations: Understanding Written and Unwritten Agreements. London, UK: Sage Publications.

Rousseau, D. M. (2000) Psychological contract in the United States. In D. M. Rousseau \& R. Schalk (Eds.) Psychological Contracts in Employment: Cross-national Perspective (pp. 250282). Thousands Oaks, CA: Sage.

Rousseau, D. M., \& Schalk, R. (2000). Psychological Contracts in Employment: Cross-national Perspectives. Thousand Oaks, CA: Sage Publications.

Rousseau, D. M., \& Tijoriwala, S. A. (1998). Assessing psychological contracts: Issues, alternatives and measures. Journal of Organizational Behavior, 19, 679-695. 
Schein, E. H. (1980). Organizational Psychology (3 ${ }^{\text {rd }}$ ed.) Englewood Cliffs, NJ: Prentice-Hall.

Schneider, B. (1983). Work climates: An interactionist perspective. In N. W. Feimer \& E. S. Geller (Eds.), Environmental Psychology: Directions and Perspectives (pp. 106-128). New York, NY: Praeger.

Scholl, R. W. (1981). Differentiating organizational commitment from expectancy as a motivating force. Academy of Management Review, 6(4), 589-599.

Schroeder, R.G., \& Flynn, B.B. (2001). High Performance Manufacturing: Global Perspectives. New York, NY: Wiley.

Schwartz, S. H. (1992). Universals in the content and structure of values: Theoretical advances and empirical tests in 20 countries. Advances in Experimental Social Psychology, 25(1), 1-65.

Schwartz, S. H. (1994). Are there universal aspects in the structure and contents of human values? Journal of Social Issues, 50(4), 19-45.

Shadur, M. A., Kienzle, R., \& Rodwell, J. J. (1999). The relationship between organizational climate and employee perceptions of involvement: The importance of support. Group \& Organization Management, 24(4), 479-503.

Shore, L.M., \& Shore, T.H. (1995). Perceived organizational support and organizational justice. In R. Cropanzano \& K. Kacmar, (Eds). Organizational Politics, Justices and Support: Managing Social Climate at Work (pp. 149-164). Westport, CT: Quorum Press.

Snell, S. A., \& Dean, J. W. (1992). Integrated manufacturing and human resource management: A human capital perspective. Academy of Management Journal, 35(3), 467-504.

Sparrow, P. R. (1998). Reappraising psychological contracting: Lessons for the field of human-resource development from cross-cultural and occupational psychology research. International Studies of Management \& Organization. 28(1): 30-63. 
Staw, B. M. (1982). Counterforces to change. In P.S. Goodman (Ed.) Change in Organizations: New Perspectives on Theory, Research, and Practice, 87-121. San Francisco, CA: Jossey-Bass.

Strauss, C., \& Quinn, N. (1997). A Cognitive Theory of Cultural Meaning (Vol.9). Cambridge University Press.

Strober, M. (1990). Human capital theory: Implications for HR managers. Industrial Relations 29, 214239.

Sturges, J., Conway, N., Guest, D., \& Liefooghe, A. (2005). Managing the career deal: The psychological contract as a framework for understanding career management, organizational commitment and work behavior. Journal of Organizational Behavior, 26(7), 821-838.

Tasa, K., Taggar, S., \& Seijts, G. H. (2007). The development of collective efficacy in teams: A multilevel and longitudinal perspective. Journal of Applied Psychology, 92(1), 17.

Thomas, D.C., Au, K., \& Ravlin, E.C. (2003). Cultural variation and the psychological contract. Journal of Organizational Behavior, 24, 451-471.

Thomas, D. C., \& Peterson, M. F. (2014). Cross-cultural Management: Essential Concepts. Thousand Oaks, CA: Sage.

Triandis, H.C. (1994). Culture and Social Behavior. New York, NY: McGraw-Hill.

Triandis, H.C. (2002). Individualism and collectivism. In M. Grannon \& K. Newman (Eds.) Handbook of cross-cultural management (pp. 16-45). New York, NY: Lawrence Erlbaum.

Triandis, H. C., \& Vassiliou, V. (1972). Interpersonal influence and employee selection in two cultures. Journal of Applied Psychology, 56(2), 140-?.

Vroom, V. H. (1964). Work and Motivation. Oxford, England: Wiley.

Weller, I., \& Gerhart, B. (2012). Empirical research issues in comparative HRM. In C. Brewster \& W. Mayrhofer, W. (Eds.) Handbook of Research on Comparative Human Resource Management (pp. 90117). Cheltenham, UK: Edward Elgar Publishing Limited. 
Wood, S., \& De Menezes, L. (1998). High commitment management in the UK: Evidence from the workplace industrial relations survey, and employers' manpower and skills practices survey. Human Relations, 51(4), 485-515.

Wright, P.M., \& Nishii, L.H. (2013). Strategic HRM and organizational behavior: Integrating multiple levels of analysis. In J. Paauwe, D. Guest, \& P. M. Wright (Eds.), HRM and Performance: Achievements and Challenges (pp. 97-11?). Chichester, UK: Wiley

Yang, K. S. (1993). Chinese social orientation: An integrative analysis. In L. Y. Cheung \& C. N. Chen (Eds.), Psychotherapy for the Chinese: Selected Papers from the First International Conference (pp. 19-56). Hong Kong: Chinese University of Hong Kong Press?. 
Table 1: Sample Plants Classified by Country and Industry

\begin{tabular}{lcccc}
\hline \multirow{2}{*}{ Country } & \multicolumn{3}{c}{ Industry } & Total \\
\cline { 2 - 4 } & Electronics & Machinery & Auto Suppliers & \\
\hline High Institutional Collectivism & & & 12 & 34 \\
$\quad$ Japan & 10 & 12 & 7 & 24 \\
$\quad$ Sweden & 7 & 7 & 4 & 21 \\
Low Institutional Collectivism & 10 & 13 & 19 & 41 \\
$\quad$ Austria & 9 & 42 & 42 & 120 \\
$\quad$ Germany & 36 & & & \\
\hline Total & & & 42 & \\
\hline
\end{tabular}


Table 2: Results of Confirmatory Factor Analyses and Inter-rater Agreement

\begin{tabular}{|c|c|c|c|}
\hline Measure & $\begin{array}{l}\text { Standardized } \\
\text { loading }\end{array}$ & $\begin{array}{l}\text { Inter-rater } \\
\text { agreement } \\
\text { Coefficient } \\
\quad\left(R_{w g}\right)\end{array}$ & $\begin{array}{l}\text { Intra-class } \\
\text { correlation } \\
\quad(\text { ICC) }\end{array}$ \\
\hline Decision making involvement & & 0.79 & 0.76 \\
\hline $\begin{array}{l}\text { Even small matters have to be referred to someone higher } \\
\text { up for a final answer. (Reverse coded) }\end{array}$ & .85 & & \\
\hline $\begin{array}{l}\text { Any decision I make has to have my boss's approval. } \\
\text { (Reverse coded) }\end{array}$ & .80 & & \\
\hline $\begin{array}{l}\text { There can be little action taken here until a supervisor } \\
\text { approves a decision. (Reverse coded) }\end{array}$ & .87 & & \\
\hline Training & & 0.87 & 0.85 \\
\hline $\begin{array}{l}\text { Our plant employees receive training and development in } \\
\text { workplace skills on a regular basis. }\end{array}$ & .87 & & \\
\hline $\begin{array}{l}\text { Management at this plant believes that continual training } \\
\text { and upgrading of employee skills is important. }\end{array}$ & .77 & & \\
\hline $\begin{array}{l}\text { Employees at this plant have skills that are above average, } \\
\text { in this industry. }\end{array}$ & .53 & & \\
\hline $\begin{array}{l}\text { Our employees regularly receive training to improve their } \\
\text { skills. }\end{array}$ & .87 & & \\
\hline Teamwork & & 0.83 & 0.84 \\
\hline $\begin{array}{l}\text { Our supervisors encourage the people who work for them } \\
\text { to work as a team. }\end{array}$ & .88 & & \\
\hline $\begin{array}{l}\text { Our supervisors encourage the people who work for them } \\
\text { to exchange opinions and ideas. }\end{array}$ & .89 & & \\
\hline $\begin{array}{l}\text { Our supervisors frequently hold group meetings where the } \\
\text { people who work for them can really discuss things } \\
\text { together. }\end{array}$ & .73 & & \\
\hline
\end{tabular}


Table 3: Variable Means, Standard Deviations, and Variable Intercorrelations

\begin{tabular}{|c|c|c|c|c|c|c|c|c|c|}
\hline & Mean & S.D. & 1 & 2 & 3 & 4 & 5 & 6 & 7 \\
\hline 1. Size & 6.09 & .90 & & & & & & & \\
\hline 2. Electronics & .30 & & -.02 & & & & & & \\
\hline 3. Machinery & .35 & & -.12 & $-.48 * *$ & & & & & \\
\hline 4. Training & 5.26 & .63 & $.23 *$ & .16 & -.12 & & & & \\
\hline 5. Teamwork & 5.32 & .61 & .05 & -.06 & -.12 & $.53 * *$ & & & \\
\hline 6. Decision making involvement & 3.85 & .79 & -.17 & .06 & .09 & $.39 * *$ & $.29 * *$ & & \\
\hline 7. Supervisor & .59 & & .04 & .07 & .05 & -.06 & .08 & .02 & \\
\hline 8. Commitment & 4.97 & 1.02 & .05 & .01 & -.05 & $.22 *$ & $.40 * *$ & .04 & $.08^{* *}$ \\
\hline
\end{tabular}

notes: $\mathrm{n}=120$ for Level 2 variables; $\mathrm{n}=1191$ for Level 1 variables (direct labor and commitment). Care should be taken when interpreting zero order correlations between Level 1 and Level 2 variables (Raudenbush \& Bryk, 2002).

$* \mathrm{p}<.05$

$* * \mathrm{p}<.01$ 
Table 4: Hierarchical Linear Modeling Results

\begin{tabular}{lcccc}
\hline & \multicolumn{2}{c}{$\begin{array}{c}\text { Low Institutional } \\
\text { Collectivism }\end{array}$} & \multicolumn{2}{c}{$\begin{array}{c}\text { High Institutional } \\
\text { Collectivism }\end{array}$} \\
\cline { 2 - 5 } & $\begin{array}{c}\text { Regression } \\
\text { Coefficient }\end{array}$ & $\begin{array}{c}\text { Standard } \\
\text { Error }\end{array}$ & $\begin{array}{c}\text { Regression } \\
\text { Coefficient }\end{array}$ & $\begin{array}{c}\text { Standard } \\
\text { Error }\end{array}$ \\
\hline Level 1 & $.33^{* *}$ & .08 & .30 & .08 \\
Supervisor & & & & \\
Level 2 & -.06 & .11 & -- & -- \\
Germany & -- & -- & .27 & .17 \\
Japan & -.11 & .09 & -.01 & .05 \\
Plant size (ln) & -.17 & .13 & .23 & .10 \\
Electronics & .12 & .10 & .00 & .11 \\
Machine & $-.06^{\mathrm{c}}$ & .11 & $.31^{* * c}$ & .07 \\
Training & $.24^{* a}$ & .10 & $.11^{a}$ & .10 \\
Decision making involvement & $.42^{* * \mathrm{~b}}$ & .09 & $.56^{* * \mathrm{~b}}$ & .09 \\
Teamwork & 2341.19 & & 977.86 & \\
Deviance & & & & \\
\hline
\end{tabular}

Notes. Coefficients are unstandardized. Coefficients across samples with the same superscript letter are significantly different form each other $\left({ }^{\mathrm{a}} p\right.$ $\left.\leq .10,{ }^{\mathrm{b}} p \leq .05,{ }^{\mathrm{c}} p \leq .01\right)$.

$* p \leq .05, * * p \leq .01$ 
APPENDIX A: Respondents Employed for Study Measures

\begin{tabular}{lll}
\hline Scale names & Respondent Classifications & $\begin{array}{c}\text { Number of Respondents } \\
\text { per Organization }\end{array}$ \\
\hline Decision making involement $^{\mathrm{a}}$ & $\begin{array}{l}\text { Direct Labor, Human Resource Manager, } \\
\text { Supervisor }\end{array}$ & 3 to 15 \\
& Human Resource Manager, Supervisor, & 3 to 6 \\
Training $^{\mathrm{a}}$ & Plant Superintendent & 3 to 14 \\
Teamwork $^{\mathrm{a}}$ & Direct Labor, Supervisor, Plant Superintendent & 3 to 14 \\
Organizational Commitment $^{\mathrm{b}}$ & Direct labor, Supervisor, Plant Superintendent & \\
\hline
\end{tabular}

Note: measures included at least one respondent from each listed respondent classification from each organization.

${ }^{\text {a }}$ Level 2 measure

${ }^{\mathrm{b}}$ Level 1 measure 
Organizational Commitment 40 